\title{
Mycobacterium avium subspecies paratuberculosis-An environmental trigger of type 1 diabetes mellitus
}

\author{
Coad Thomas Dow
}

Eye Research Institute, University of Wisconsin-Madison, Madison, USA; ctdow@me.com

Received 28 July 2011; revised 31 November 2011; accepted 19 December 2011

\begin{abstract}
Type 1 diabetes mellitus (T1DM) is an autoimmune disease. The etiology of T1DM is incompletely understood but environmental agent(s) are thought to trigger T1DM in the genetically at-risk. Humans are widely exposed to Mycobacterium avium subspecies paratuberculosis (MAP), a proven multi-host chronic enteric pathogen that is mostly studied in ruminant animals and causes the inflammatory disease paratuberculosis or Johne's disease. In humans, MAP is the putative cause of Crohn's disease and has been linked to sarcoidosis, autoimmune thyroiditis, multiple sclerosis and autoimmune diabetes. The role of MAP as a trigger for T1DM was first postulated in 2005; subsequent studies suggest a link. This article discusses MAP, human exposure to MAP, genetic susceptibility to MAP and MAP in human disease including T1DM.
\end{abstract}

Keywords: Autoimmune Diabetes; T1DM; Paratuberculosis; MAP; HSP65; Molecular Mimicry

\section{INTRODUCTION}

The etiology of T1DM is incompletely understood but environmental agent(s) are thought to trigger T1DM in the genetically at-risk. In the United States the prevalence of T1DM is increasing and is approximately 1 in 300 by 18 years of age. Research into risk factors for T1DM is an active area with attempts to identify genetic and environmental triggers that could potentially be targeted for intervention [1].

Evidence supports a critical role of exogenous factors in the development of T1DM: 1 ) less than $10 \%$ of individuals with HLA-conferred diabetes susceptibility progress to clinical disease; 2) pair-wise concordance of T1DM of less than $40 \%$ among monozygotic twins; 3 ) greater than 10 -fold difference in the disease incidence among Caucasians living in Europe, (annual rate Macedonia 3.2/100,000 vs. Finland 54/100,000); 4) severalfold increase in the incidence over the last 50 years; and 5) migration studies that indicate disease incidence increases in population groups who have moved from a low-incidence to a high-incidence region [2].

The postulate that MAP plays a causal role in T1DM was presented at the 2005 Colloquium on Paratuberculosis [3] and published in 2006 [4]. To understand the rationale of the hypothesis it is necessary to review MAP, the role MAP plays in animal disease and the proposed role MAP has in human disease.

\section{MYCOBACTERIUM AVIUM SS. PARATUBERCULOSIS (MAP)}

MAP is a gram-positive, acid-fast staining small rodshaped bacterium. As with members of the Mycobacteriaceae genus, it has a unique cell wall structure rich in complex lipids. The thick and chemically distinctive cell wall of mycobacteria is responsible in large measure for the robust nature of these bacteria, both within the host cell and in the environment. The pathogenic potential of mycobacteria is correlated with their growth rate. Paradoxically, slow-growing mycobacteria are more virulent than fast-growing mycobacteria. With the exception of Mycobacterium leprae (the cause of leprosy in humans), which cannot be cultured in vitro, MAP has the slowest growth rate of pathogenic mycobacteria. After isolation from infected animals and grown under optimal conditions colonies of MAP are typically not visible for 3 months or more [5].

Mycobacterium avium subspecies paratuberculosis (MAP) causes a chronic granulomatous inflammation of the intestines in ruminant animals called Johne's disease. Mostly studied in dairy cattle, goats and sheep, MAP also causes a chronic inflammation of the intestines in beef cattle and in a wide variety of other domestic and wild ruminants. MAP-induced enteric inflammation has been found in monogastric animals including dogs and pigs as 
well as four different types of subhuman primatesmacaques, baboons, gibbons and cotton-top tamarins"' [6]. A majority of the dairy herds in the United States and Europe have infected animals within the herd [7].

\section{MAP and Human Exposure}

MAP is present in pasteurized milk [8,9], infant formula made from pasteurized milk [10], surface water [11, 12], soil [11], cow manure "lagoons" that leach into surface water, cow manure in both solid and liquid forms that is applied as fertilizer to agricultural land [13,14], and municipal tap water [5], providing multiple routes of transmission to humans. In a recent study in Ohio the DNA of MAP was detected in over $80 \%$ of domestic water samples [15].

\section{MAP AND HUMAN DISEASE- INFLAMMATORY BOWEL DISEASE AND SARCOIDOSIS}

In addition to Johne's disease of animals, MAP is the putative cause of the striking similar Crohn's disease of humans. Although there has been a century-long debate, the role of MAP in Crohn's has evolved from controversial to compelling [16-18]. The major source of the debate is that conventional methods of detecting bacterianamely, culture and stain-are largely ineffective in detecting MAP. However, with newer laboratory techniques, primarily PCR, evidence of MAP is readily found in Crohn's tissues $[19,20]$. MAP can be identified within the granulomas by in situ hybridization [21]: and, with extreme care and patience, MAP can be grown from the gut and blood of Crohn's patients [22-24].

In addition to Crohn's MAP has been reported as a candidate pathogen in the causation of irritable bowel syndrome [25] and some suspect that MAP causes the spectrum of inflammatory bowel disease including Crohn's, ulcerative colitis and irritable bowel syndrome [26]. Irritable bowel syndrome is a widespread abdominal condition that affects about 10 to $15 \%$ of people in the industrialized economies of Europe, North America, Australasia, and Japan, with a rising prevalence among the populations in the developing economies of Asia. Some consider irritable bowel syndrome a form fruste of Crohn's disease [27].

In addition to inflammatory bowel disease MAP has been historically linked is sarcoidosis; a multi-system inflammatory disease in which DNA evidence of MAP has been found (sporadically) in sarcoid granulomas [28].

\section{GENETICS AND T1DM}

Early studies indicated that the HLA region on chromosome 6p21 (commonly termed IDDM1, for insu- lin-dependent diabetes mellitus locus) is a critical susceptibility locus for T1DM [29,30]. A comprehensive review of the genetics of T1DM is beyond the scope of this article; instead, we will focus on a gene that appears to be permissive to both MAP and T1DM (SLC11A1).

Natural resistance-associated macrophage protein 1 (NRAMP1) is now strictly referred to as SLC11A1 (solute carrier 11a1). The gene that encodes for this protein is recognized as having a role in the susceptibility of humans and animals to a number of infections, including mycobacterial infections, and is associated with a number of autoimmune diseases as well. In human beings, the SLC11A1 gene is located on chromosome 2q35. It encodes an integral membrane protein of 550 amino acids that is expressed exclusively in the lysosomal compartment of monocytes and macrophages [31].

The product of the SLC11A1 gene modulates the cellular environment in response to activation by intracellular pathogens by acidifying the phagosome thus killing the pathogen [32]. As such, it plays a role in host innate immunity [33]. Mutation of SLC11A1 impairs phagosome acidification yielding a permissive environment for the persistence of intracellular bacteria [34].

\section{SLC11A1 IN INFECTIOUS AND AUTOIMMUNE DISEASE}

Sarcoidosis, the previously mentioned systemic disease associated with MAP, is also associated with polymorphisms of the SLC11A1 gene [35]. Susceptibility to mycobacterial diseases tuberculosis, leprosy and Buruli's ulcer are associated with polymorphism of the SLC11A1 gene [36]. Similar polymorphisms are associated with Johne's disease (paratuberculosis) in cattle [37], goats [38], and sheep [39]. When researchers at the Belgium Pasteur Institute developed a murine model for MAP infection, they created an SLC11A1 defect mouse [40].

Given the pivotal roles that SLC11A1 plays in innate immunity, it is not surprising that the relationship between polymorphisms in SLC11A1 and a number of mycobacterial as well as autoimmune diseases has been explored [41]. Associations have been found with leprosy [42], tuberculosis [43], rheumatoid arthritis [44], visceral leishmaniasis [45], multiple sclerosis [46,47], inflammatory bowel disease [48-50], and type 1 diabetes mellitus [51,52].

\section{MAP AND TYPE 1 DIABETES}

Type 1 diabetes mellitus (T1DM) is an autoimmune disease manifest by progressive $\mathrm{T}$ cell-mediated autoimmune destruction of insulin-producing beta cells in the pancreatic islets of Langherans [53]. In 2005 Dow postulated a causative role for MAP in the T1DM; Sechi in 2007 found the DNA of MAP in the blood of autoimmune 
(type 1) patients but not non-autoimmune (type 2) diabetics [54-56]. Sechi also found an association of polymorphisms of the SLC11a1 gene and MAP in T1DM patients [51].

The link connecting MAP and T1DM comes from the concept of molecular mimicry: protein elements of the pathogen share sequence and/or conformational elements with the host to a degree that immune responses directed at the pathogen also attack the host. A proposed link is the mimicry of mycobacterial heat shock protein of MAP (HSP65) and pancreatic glutamic acid decarboxylase (GAD) [4].

\section{MOLECULAR MIMICRYIHEAT SHOCK PROTEINS-HSP65}

Molecular mimicry has long been implicated as a mechanism by which microbes can induce autoimmunity [57]. Rheumatic fever is the classic example for molecular mimicry between an infecting agent-Streptococcus pyogenes (group A streptococcus) and a related autoimmune disease in humans [58]. The disease is characterized by damage to the heart, joints, and the central nervous system (Sydenham's chorea). The activity of the host's immune system against the streptococcus generates a cross-recognition to human tissue causing an autoimmune reaction [59].

Heat shock proteins (HSPs) are produced in response to environmental stress. They act in a protective capacity helping cells survive stressful conditions and promoting recovery [60]. Mycobacterial HSPs have been found in several autoimmune diseases [61]. For example, the mycobacterial $65 \mathrm{kDa}$ HSP has been implicated in the pathogenesis of rheumatoid arthritis [62], autoimmune hepatitis [63], primary biliary cirrhosis [64] and scleroderma [65]. HSP65 is implicated in multiple vasculitis-associated systemic autoimmune diseases such as Kawasaki disease [66], Behcet's disease [67] and Takayasu's arteritis [68].

\section{MOLECULAR MIMICRY AND TYPE 1 DIABETES MELLITUS}

Individuals at-risk for T1DM produce anti-GAD antibodies. HSP65 was first associated with T1DM via GAD in 1990 [69]. Mycobacteria produce HSP65 in response to stress. Epitope homology between MAP/human HSP60/65 and pancreatic glutamic acid decarboxylase (GAD) likely triggers the anti-GAD antibodies that secondarily destroy the pancreas [70].

\section{T1DM AND MILK}

Several studies indicate an association between early exposure to dietary cow's milk and an increased risk of TIDM [71-73]. These studies were prompted by the ob- servation that children at risk for TIDM who were breast fed exclusively for more than six months were less likely to have TIDM later in life than similar risk children who were weaned onto cow's milk-based formula at an earlier age. This observation spawned a large study, the TRIGR study: Trial to Reduce IDDM in the Genetically at Risk [74]. The postulate is that there is something about cow's milk protein that is an immunologic trigger for TIDM and that breaking the protein with hydrolysis may eliminate the trigger. The TRIGR study is an ongoing, 17-country study enlisting 6200 infants who are genetically at risk to develop TIDM. Children weaned early from breastfeeding are randomized into two groups; one receiving traditional cow's milk-based formula and the other receiving formula in which the protein has been hydrolyzed. A recent, smaller but somewhat parallel study shows that exposure to the hydrolyzed infant formula resulted in lessened incidence of T1DM [75]. Antibodies against specific MAP proteins were found in Sardinian children involved in the TRIGR study (Sechi, personal communication) as previously mentioned, viable MAP has been found in infant formula powder [10].

\section{MAP AND OTHER AUTOIMMUNE DISEASE-THYROIDITIS AND MULTIPLE SCLEROSIS}

Two recent articles link MAP to autoimmune (Hashimoto's) thyroiditis. The same molecular mimicry principle is suggested as the link between MAP (HSP65) and the organ-specific autoantigens of thyroiditis [76,77]. Also, a recent article implicate MAP in multiple sclerosis [78]. Molecular mimicry and SLC11A1 associations are germane here as well [79].

\section{MAP AND T1DM-THE FUTURE}

While evidence mounts that MAP is, indeed, a zoonotic agent, what policies and interventions might be employed to address curtailing MAP and the effects of its persistence in individuals? Presently, sound farm management practices and stringent culling are considered the best means to reduce the spread of MAP from animal to animal, as well as from farm to farm [80]. However, because such practices have yet to eliminate MAP from food animals, other preventive or curative measures are needed.

TASF is a Swiss-based international forum for Transmissible Animal Diseases and Food Safety. TASF acknowledges the uncertainties of the zoonotic potential of MAP for Crohn's disease. TASF suggests that

“... a decision by food safety regulators to exercise the "precautionary principle", label MAP as a potential zoonotic agent, and adopt measures to limit as much as possible the levels of MAP contamination of raw milk and meat would go far to protect the coming generations of 
children from MAP exposure, possible infection, and potentially Crohn's disease." [81].

Preliminary studies with a probiotic of the Dietzia species have been shown effective in treating clinically ill adult cows with Johne's disease and in preventing Johne's in calves [82,83]. The use of Dietzia has also been suggested for individuals with inflammatory bowel disease [84]. Vaccines are effective in reducing the incidence of clinical Johne's disease $[85,86]$ and attenuate pre-existing infection [87]. However, such whole killed vaccines do not eliminate subclinical MAP infection or its persistence in the gut. Additionally, about half of the animals receiving whole killed MAP vaccines become false positive using the conventional tuberculin skin test diagnostic for bovine tuberculosis [88] DNA vaccination may have an interesting application: [89] showed that lambs vaccinated with plasmids encoding mycobacterial antigens produced a Th1 immune response similar to that generated by natural infection by MAP. Lambs vaccinated with DNA mycobacterial antigens (HSP65) were protected against MAP infection. Unfolding knowledge regarding susceptibility polymorphism of genes such as the SLC11a1 gene described in this article may lead to breeding practices that would limit MAP infection in breeding lines thus keeping it from the human food chain.

In humans with MAP-associated disease recognition of both the need to treat as an infectious disease as well as the need to avoid further exposure is paramount. Aggressive anti-mycobacterial treatment has had beneficial effect in those who can tolerate the treatment [90,91]. Vaccines against MAP for use in humans are being advocated and prototypes are being developed [92].

\section{CONCLUSION}

The controversy regarding MAP and human disease has been going for a century and will likely continue for a long time. T1DM has only recently been added to the discussion and controversy. In addition to the human toll to individuals with T1DM, the dollar cost is extreme; the burden is passed to all of society in the form of higher insurance premiums and taxes, reduced earnings, and reduced standard of living [93]. These issues should elevate the discussion, draw resources and bring a sense of urgency to the MAP/T1DM connection.

\section{REFERENCES}

[1] Maahs, D.M., West, N.A., Lawrence, J.M. and Mayer-Davis, E.J. (2010) Epidemiology of type 1 diabetes. Endocrinology and Metabolism Clinics of North America, 39, 481-497.

[2] Knip, M., Veijola, R., Virtanen, S.M., Hyöty, H., Vaarala, O. and Akerblom, H.K. (2005) Environmental triggers and determinants of type 1 diabetes. Diabetes, 54,
S125-S136. doi:10.2337/diabetes.54.suppl_2.S125

[3] Dow, CT. (2005) Paratuberculosis and type I diabetes mapping the TRIGR. Proceedings of the 8th International Colloquium on Paratuberculosis, August 2005, Copenhagen, Denmark, Available from:

http://www.paratuberculosis.org/pubs/proc8/abst3b_020.h $\underline{\mathrm{tm}}$

[4] Dow, CT. (2006) Paratuberculosis and type I diabetes: Is this the trigger? Medical Hypotheses, 67, 782-785. doi:10.1016/j.mehy.2006.04.029

[5] Collins, M.T. (2003) Paratuberculosis: Review of present knowledge. Acta Veterinaria Scandinavica, 44, 217-221.

[6] Hermon-Taylor, J., Bull, T.J., Sheridan, J.M., Cheng, J., Stellakis, M.L., et al. (2000) Causation of Crohn's disease by Mycobacterium avium subspecies paratuberculosis. Canadian Journal of Gastroenterology, 14, 521-539.

[7] Stabel, J.R. (1998) Johne's disease: A hidden threat. Journal of Dairy Science, 81, 283-288. doi:10.3168/jds.S0022-0302(98)75577-8

[8] Millar, D., Ford, J., Sanderson, J., Withey, S., Tizard, M., et al. (1996) IS900 PCR to detect Mycobacterium paratuberculosis in retail supplies of whole pasteurized cows' milk in England and Wales. Applied and Environmental Microbiology, 62, 3446-3452.

[9] Ellingson, J.L., Anderson, J.L., Koziczkowski, J.J., Radcliff, R.P., Sloan, S.J., Allen, S.E. and Sullivan, N.M. (2005) Detection of viable Mycobacterium avium subsp. paratuberculosis in retail pasteurized whole milk by two culture methods and PCR. Journal of Food Protection, 68, 966-972.

[10] Hruska, K., Bartos, M., Kralik, P. and Pavlik, I. (2005) Mycobacterium avium subsp. paratuberculosis in powdered infant milk: Paratuberculosis in cattle-The public health problem to be solved. Veterinarni MedicinaCzech, 50, 327-335.

[11] Pickup, R.W., Rhodes, G., Arnott, S., Sidi-Boumedine, K., Bull, T.J., et al. (2005) Mycobacterium avium subsp. paratuberculosis in the catchment area and water of the River Taff in South Wales, United Kingdom, and its potential relationship to clustering of Crohn's disease cases in the city of Cardiff. Applied and Environmental Microbiology, 71, 2130-2139. doi:10.1128/AEM.71.4.2130-2139.2005

[12] Whan, L., Ball, H.J., Grant, I.R. and Rowe, M.T. (2005) Occurrence of Mycobacterium avium subsp. paratuberculosis in untreated water in Northern Ireland. Applied and Environmental Microbiology, 71, 7107-7112. doi:10.1128/AEM.71.11.7107-7112.2005

[13] Grewal, S.K., Rajeev, S., Sreevatsan, S. and Michel, F.C. Jr. (2006) Persistence of Mycobacterium avium subsp. paratuberculosis and other zoonotic pathogens during simulated composting, manure packing, and liquid storage of dairy manure. Applied and Environmental Microbiology, 72, 565-574. doi:10.1128/AEM.72.1.565-574.2006

[14] Gill, C.O., Saucier, L. and Meadus, W.J. (2011) Mycobacterium avium subsp. paratuberculosis in dairy products, meat, and drinking water. Journal of Food Protection, 74, 480-499. doi:10.4315/0362-028X.JFP-10-301 
[15] Beumer, A., King, D., Donohue, M., Mistry, J., Covert, T. and Pfaller, S. (2010) Detection of Mycobacterium avium subsp. paratuberculosis in drinking water and biofilms by quantitative PCR. Applied and Environmental Microbiology, 76, 7367-7370.

[16] Chamberlin, W., Borody, T. and Naser, S. (2007) MAPassociated Crohn's disease MAP, Koch's postulates, causality and Crohn's disease. Digestive and Liver Disease, 39, 792-794. doi:10.1016/j.dld.2007.05.012

[17] Feller, M., Huwiler, K., Stephan, R., Altpeter, E., Shang, A., Furrer, H., Pfyffer, G.E., Jemmi, T., Baumgartner, A. and Egger, M. (2007) Mycobacterium avium subspecies paratuberculosis and Crohn's disease: A systematic review and meta-analysis. Lancet Infectious Diseases, 7, 607-613. doi:10.1016/S1473-3099(07)70211-6

[18] Mendoza, J.L., San-Pedro, A., Culebras, E., Cíes, R., Taxonera, C., Lana, R., Urcelay, E., de la Torre, F., Picazo, J.J. and Díaz-Rubio, M. (2010) High prevalence of viable Mycobacterium avium subspecies paratuberculosis in Crohn's disease. World Journal of Gastroenterology, 16, 4558-4563. doi:10.3748/wjg.v16.i36.4558

[19] Chiodini, R.J. (1989) Crohn's disease and the mycobacterioses: A review and comparison of two disease entities. Clinical Microbiology Reviews, 2, 90-117.

[20] McFadden, J.J., Butcher, P.D., Chiodini, R. and HermonTaylor, J. (1987) Crohn's disease-isolated mycobacteria are identical to M. para, as determined by DNA probes that distinguish between mycobacterial species. Journal of Clinical Microbiology, 25, 796-801.

[21] Sechi, L.A., Mura, M., Tanda, F., et al. (2001) Identification of Mycobacterium avium subsp. paratuberculosis in biopsy specimens from patients with Crohn's disease identified by in situ hybridization. Journal of Clinical Microbiology, 39, 4514-4527. doi:10.1128/JCM.39.12.4514-4517.2001

[22] Naser, S.A., Ghobrial, G., Romero, C. and Valentine, J.F. (2004) Culture of Mycobacterium avium subspecies paratuberculosis from the blood of patients with Crohn's disease. Lancet, 364, 1039-1044. doi:10.1016/S0140-6736(04)17058-X

[23] Naser, S.A., Collins, M.T., Crawford, J.T. and Valentine, J.F. (2009) Culture of Mycobacterium avium subspecies paratuberculosis (MAP) from the blood of patients with crohn's disease: a follow-up blind multi center investigation. The Open Inflammation Journal, 2, 22-23. doi:10.2174/1875041900902010022

[24] Sechi, L.A., Scanu, A.M., Molicotti, P., et al. (2005) Detection and Isolation of Mycobacterium avium subspecies paratuberculosis from intestinal mucosal biopsies of patients with and without Crohn's disease in Sardinia. American Journal of Gastroenterology, 100, 1529-1536. doi:10.1111/j.1572-0241.2005.41415.x

[25] Scanu, A.M., Bull, T.J., Cannas, S., Sanderson, J.D., Sechi, L.A., Dettori, G., Zanetti, S. and Hermon-Taylor, J. (2007) Mycobacterium avium subspecies paratuberculosis infection in cases of irritable bowel syndrome and comparison with Crohn's disease and Johne's disease: Common neural and immune pathogenicities. Journal of Clinical Microbiology, 45, 3883-3890.

\section{doi:10.1128/JCM.01371-07}

[26] Pierce, E.S. (2010) Ulcerative colitis and Crohn's disease: Is Mycobacterium avium subspecies paratuberculosis the common villain? Gut Pathog, 2, 21. doi:10.1186/1757-4749-2-21

[27] Olbe, L. (2008) Concept of Crohn's disease being conditioned by four main components, and irritable bowel syndrome being an incomplete Crohn's disease. Scandinavian Journal of Gastroenterology, 43, 234-241. doi:10.1080/00365520701676971

[28] el-Zaatari, F.A.K., Naser, S.A., Markesich, D.C., Kalter, D.C., Engstand, L. and Graham, D.Y. (1996) Identification of Mycobacterium avium complex in sarcoidosis. Journal of Clinical Microbiology, 34, 2240-2245.

[29] Nerup, J., Platz, P., Andersen, O.O., Christy, M., Lyngsoe, J. (1974) HL-A antigens and diabetes mellitus. Lancet, 2, 864-866. doi:10.1016/S0140-6736(74)91201-X

[30] Singal, D.P. and Blajchman, M.A. (1973) Histocompatibility (HL-A) antigens, lymphocytotoxic antibodies and tissue antibodies in patients with diabetes mellitus. Diabetes, 22, 429-432.

[31] Canonne-Hergaux, F., Gruenheid, S., Govoni, G. and Gros, P. (1999) The Nramp1 protein and its role in resistance to infection and macrophage function. Proceedings of the Association of American Physicians, 111, 283-289. doi:10.1046/j.1525-1381.1999.99236.x

[32] Lapham, A.S., Phillips, E.S. and Barton, C.H. (2004) Transcriptional control of Nramp1: A paradigm for the repressive action of c-Myc. Biochemical Society Transactions, 32, 1084-1086.

[33] Wyllie, S., Seu, P. and Goss, J.A. (2002) The natural resistance-associatedmacrophage protein 1 Slc11a1 (formerly Nramp1) and iron metabolism in macrophages. Microbes and Infection, 4, 351-359. doi:10.1016/S1286-4579(02)01548-4

[34] Hackam, D.J., Rotstein, O.D., Zhang, W., Gruenheid, S., Gros, P. and Grinstein, S. (1998) Host resistance to intracellular infection: Mutation of natural resistance-associated macrophage protein 1 (Nramp1) impairs phagosomal acidification. Journal of Experimental Medicine, 188 351-364. doi:10.1084/jem.188.2.351

[35] Dubaniewicz, A., Jamieson, S.E., Dubaniewicz-Wybieralska, M., Fakiola, M., Nancy Miller, E. and Blackwell, J.M. (2005) Association between SLC11A1 (formerly NRAMP1) and the risk of sarcoidosis in Poland. European Journal of Human Genetics, 13, 829-834. doi:10.1038/sj.ejhg.5201370

[36] Stienstra, Y., van der Werf, T.S., Oosterom, E., Nolte, I.M., van der Graaf, W.T., Etuaful, S., Raghunathan, P.L., Whitney, E.A., Ampadu, E.O., Asamoa, K., Klutse, E.Y., te Meerman, G.J., Tappero, J.W., Ashford, D.A. and van der Steege, G. (2006) Susceptibility to Buruli ulcer is associated with the SLC11A1 (NRAMP1) D543N polymorphism. Genes \& Immunity, 7, 185-189. doi:10.1038/sj.gene.6364281

[37] Ruiz-Larrañaga, O., Garrido, J.M., Manzano, C., Iriondo, M., Molina, E., Gil, A., Koets, A.P., Rutten, V.P., Juste, R.A. and Estonba, A. (2010) Identification of single nu- 
cleotide polymorphisms in the bovine solute carrier family 11 member 1 (SLC11A1) gene and their association with infection by Mycobacterium avium subspecies paratuberculosis. Journal of Dairy Science, 93, 17131721. doi:10.3168/jds.2009-2438

[38] Korou, L.M., Liandris, E., Gazouli, M. and Ikonomopoulos, J. (2010) Investigation of the association of the SLC11A1 gene with resistance/sensitivity of goats (Capra hircus) to paratuberculosis. Veterinary Microbiology, 144, 353-358. doi:10.1016/j.vetmic.2010.01.009

[39] Purdie, A.C., Plain, K.M., Begg, D.J., de Silva, K. and Whittington, R.J. (2011) Candidate gene and genomewide association studies of Mycobacterium avium subsp. paratuberculosis infection in cattle and sheep: A review. Comparative Immunology, Microbiology and Infectious Diseases, 34, 197-208.

[40] Roupie, V., Rosseels, V., Piersoel, V., Zinniel, D.K., Barletta, R.G. and Huygen, K. (2008) Genetic resistance of mice to Mycobacterium paratuberculosis is influenced by Slc11a1 at the early but not at the late stage of infection. Infection and Immunity, 76, 2099-2105. doi:10.1128/IAI.01137-07

[41] Blackwell, J.M., Searle, S., Mohamed, H. and White, J.K. (2003) Divalentcation transport and susceptibility to infectious and autoimmune disease: Continuation of the Ity/ Lsh/Bcg/Nramp1/Slc11a1 gene story. Immunology Letters, 85, 197-203. doi:10.1016/S0165-2478(02)00231-6

[42] Hatta, M., Ratnawati, Tanaka, M., Ito, J., Shirakawa, T. and Kawabata, M. (2010) NRAMP1/SLC11A1 gene polymorphisms and host susceptibility to Mycobacterium tuberculosis and M. leprae in South Sulawesi, Indonesia. Southeast Asian Journal of Tropical Medicine and Public Health, 41, 386-394.

[43] Bellamy, R., Ruwende, C., Corrah, T., McAdam, K.P., Whittle, H.C. and Hill, A.V. (1998) Variations in the NRAMP1 gene and susceptibility to tuberculosis in West Africans. New England Journal of Medicine, 338, 640644. doi:10.1056/NEJM199803053381002

[44] Ates, O., Dalyan, L., Musellim, B., Hatemi, G., Turker, H., Ongen, G., Hamuryudan, V. and Topal-Sarikaya, A. (2009) NRAMP1 (SLC11A1) gene polymorphisms that correlate with autoimmune versus infectious disease susceptibility in tuberculosis and rheumatoid arthritis. Journal of Immunogenetics, 36, 15-19. doi:10.1111/j.1744-313X.2008.00814.X

[45] Mohamed, H.S., Ibrahim, M.E., Miller, E.N., White, J.K., Cordell, H.J., Howson, J.M., Peacock, C.S., Khalil, E.A., El Hassan, A.M. and Blackwell, J.M. (2004) SLC11A1 (formerly NRAMP1) and susceptibility to visceral leishmaniasis in the Sudan. European Journal of Human Genetics, 12, 66-74. doi:10.1038/sj.ejhg.5201089

[46] Kotze, M.J., de Villiers, J.N., Rooney, R.N., Grobbelaar, J.J., Mansvelt, E.P., Bouwens, C.S., Carr, J., Stander, I. and du Plessis, L. (2001) Analysis of the NRAMP1 gene implicated in iron transport: Association with multiple sclerosis and age effects. Blood Cells, Molecules \& Diseases, 27, 44-53. doi:10.1006/bcmd.2000.0349

[47] Gazouli, M., Sechi, L., Paccagnini, D., Sotgiu, S., Arru, G., et al. (2008) NRAMP1 polymorphism and viral fac- tors in Sardinian multiple sclerosis patients. Canadian Journal of Neurological Sciences, 35, 491-494.

[48] Gazouli, M., Atsaves, V., Mantzaris, G., Economou, M., Nasioulas, G., Evangelou, K., Archimandritis, A.J. and Anagnou, N.P. (2008) Role of functional polymorphisms of NRAMP1 gene for the development of Crohn's disease. Inflammatory Bowel Diseases, 14, 1323-1330. doi:10.1002/ibd.20488

[49] Kotlowski, R., Bernstein, C.N., Silverberg, M.S. and Krause, D.O. (2008) Population-based case-control study of alpha 1-antitrypsin and SLC11A1 in Crohn's disease and ulcerative colitis. Inflammatory Bowel Diseases, 14, 1112-1117. doi:10.1002/ibd.20425

[50] Sechi, L.A., Gazouli, M., Sieswerda, L.E., Molicotti, P., Ahmed, N., Ikonomopoulos, J., Scanu, A.M., Paccagnini, D. and Zanetti, S. (2006) Relationship between Crohn's disease, infection with Mycobacterium avium subspecies paratuberculosis and SLC11A1 gene polymorphisms in Sardinian patients. World Journal of Gastroenterology, 12, 7161-7164.

[51] Paccagnini, D., Sieswerda, L., Rosu, V., Masala, S., Pacifico, A., Gazouli, M., Ikonomopoulos, J., Ahmed, N., Zanetti, S. and Sechi, L.A. (2009) Linking chronic infection and autoimmune diseases: Mycobacterium avium subspecies paratuberculosis, SLC11A1 polymorphisms and type-1 diabetes mellitus. PLoS One, 214, e7109. doi:10.1371/journal.pone.0007109

[52] Takahashi, K., Satoh, J., Kojima, Y., Negoro, K., Hirai, M., Hinokio, Y., Kinouchi, Y., Suzuki, S., Matsuura, N., Shimosegawa, T. and Oka, Y. (2004) Promoter polymorphism of SLC11A1 (formerly NRAMP1) confers susceptibility to autoimmune type 1 diabetes mellitus in Japanese. Tissue Antigens, 63, 231-236. doi:10.1111/j.1399-0039.2004.000172.x

[53] Eisenbarth, G.S. (1986) Type I diabetes mellitus. A chronic autoimmune disease. New England Journal of Medicine, 314, 1360-1368.

[54] Rosu, V., Ahmed, N., Paccagnini, D., Gerlach, G., Fadda, G., Hasnain, S.E., Zanetti, S. and Sechi, L.A. (2009) Specific immunoassays confirm association of Mycobacterium avium Subsp. paratuberculosis with type-1 but not type-2 diabetes mellitus. PLoS One, 4, e4386. doi:10.1371/journal.pone.0004386

[55] Sechi, L.A., Ruehl, A., Ahmed, N., Usai, D., Paccagnini, D., Felis, G.E. and Zanetti, S. (2007) Mycobacterium avium subspecies paratuberculosis infects and multiplies in enteric glial cells. World Journal of Gastroenterology, 13, 5731-5735.

[56] Sechi, L.A., Rosu, V., Pacifico, A., Fadda, G., Ahmed, N. and Zanetti, S. (2008) Humoral immune responses of type 1 diabetes patients to Mycobacterium avium subsp. paratuberculosis lend support to the infectious trigger hypothesis. Clinical and Vaccine Immunology, 15, 320326. doi:10.1128/CVI.00381-07

[57] Oldstone, M.B. (1987) Molecular mimicry and autoimmune disease. Cell, 50, 819-820. doi:10.1016/0092-8674(87)90507-1

[58] Guilherme, L., Faé, K., Oshiro, S.E. and Kalil, J. (2005) Molecular pathogenesis of rheumatic fever and rheumatic 
heart disease. Expert Reviews in Molecular Medicine, 7, 1-15. doi:10.1017/S146239940501015X

[59] Raska, M. and Weigl, E. (2005) Heat shock proteins in autoimmune diseases. Biomedical Papers of the Medical Faculty of the University Palacký, Olomouc Czech Republic, 149, 243-249.

[60] Parsell, D.A. and Lindquist, S. (1993) The function of heat-shock proteins in stress tolerance: Degradation and reactivation of damaged proteins. Annual Review of $\mathrm{Ge}$ netics, 27, 437-496.

doi:10.1146/annurev.ge.27.120193.002253

[61] Jarjour, W.N., Jeffries, B.D., Davis IV, J.S., et al. (1991) Autoantibodies to human stress proteins. A survey of various rheumatic and other inflammatory diseases. Arthritis Rheum, 34, 1133-1138. doi:10.1002/art.1780340909

[62] Moudgil, K.D., Chang, T.T., Eradat, H., et al. (1997) Diversification of $\mathrm{T}$ cell responses to carboxy-terminal determinants within the $65 \mathrm{kD}$ heat-shock protein is involved in regulation of autoimmune arthritis. Journal of Experimental Medicine, 185, 1307-1316. doi:10.1084/jem.185.7.1307

[63] Miyata, M., Kogure, A., Sato, H., et al. (1995) Detection of antibodies to $65 \mathrm{KD}$ heat shock protein and to human superoxide dismutase in autoimmune hepatitis-molecular mimicry between $65 \mathrm{KD}$ heat shock protein and superoxide dismutase. Clinical Rheumatology, 14, 673-677. doi:10.1007/BF02207935

[64] Vilagut, L., Pares, A., Vinas, O., et al. (1992) Antibodies to mycobacterial $65 \mathrm{kD}$ heat shock protein cross-react with the main mitochondrial antigens in patients with primary biliary cirrhosis. European Journal of Clinical Investigation, 27, 667-672. doi:10.1046/j.1365-2362.1997.1690724.x

[65] Danieli, M.G., Candela, M., Ricciatti, A.M., et al. (1992) Antibodies to mycobacterial $65 \mathrm{kDa}$ heat shock protein in systemic sclerosis (scleroderma). Journal of Autoimmunity, 5, 443-445. doi:10.1016/0896-8411(92)90004-A

[66] Yokota, S., Tsubaki, S., Kuriyama, T., et al. (1993) Presence in Kawasaki disease of antibodies to mycobacterial heatshock protein HSP65 and autoantibodies to epitopes of human HSP65 cognate antigen. Clinical Immunology and Immunopathology, 67, 163-170.

[67] Direskeneli, H. and Saruhan-Direskeneli, G. (2003) The role of heat shock proteins in Behcet's disease. Clinical and Experimental Rheumatology, 21, S44-S48. doi:10.1006/clin.1993.1060

[68] Aggarwal, A., Chag, M., Sinha, N. and Naik, S. (1996) Takayasu's arteritis: Role of Mycobacterium tuberculosis and its $65 \mathrm{kDa}$ heat shock protein. International Journal of Cardiology, 55, 49-55. doi:10.1016/0167-5273(96)02660-5

[69] Jones, D.B., Hunter, N.R. and Duff, G.W. (1990) Heatshock protein 65 as a beta cell antigen of insulin-dependent diabetes. Lancet, 336, 583-585. doi:10.1016/0140-6736(90)93390-B

[70] Jones, D.B., Coulson, A.F. and Duff, G.W. (1993) Sequence homologies between hsp60 and autoantigens. Immunology Today, 14, 115-118.
doi:10.1016/0167-5699(93)90210-C

[71] Akerblom, H.K. and Knip, M. (1998) Putative environmental factors in Type 1 diabetes. Diabetes/Metabolism Reviews, 14, 31-67. doi:10.1002/(SICI)1099-0895(199803)14:1<31::AID-DM R201>3.0.CO;2-A

[72] Gerstein, H.C. (1994) Cow’s milk exposure and Type I diabetes mellitus. A critical overview of the clinical literature. Diabetes Care, 17, 13-19. doi:10.2337/diacare.17.1.13

[73] Gimeno, S.G. and de Souza, J.M. (1997) DM and milk consumption. A case-control study in Sao Paulo, Brazil. Diabetes Care, 20, 1256-1260. doi:10.2337/diacare.20.8.1256

[74] Akerblom, H.K. (2010) The TRIGR study group. The Trial to Reduce IDDM in the Genetically at Risk (TRIGR) study: Recruitment, intervention and follow-up. Diabetologia, 54, 627-633.

[75] Knip, M., Virtanen, S.M., Seppä, K., Ilonen, J., Savilahti, E., Vaarala, O., Reunanen, A., Teramo, K., Hämäläinen, A.M., Paronen, J., Dosch, H.M., Hakulinen, T. and Akerblom, H.K. (2010) Dietary intervention in infancy and later signs of beta-cell autoimmunity. Finnish TRIGR Study Group. New England Journal of Medicine, 363, 1900-1908. doi:10.1056/NEJMoa1004809

[76] D’Amore, M., Lisi, S., Sisto, M., Cucci, L. and Dow, C.T. (2010) Molecular identification of Mycobacterium avium subspecies paratuberculosis in an Italian patient with Hashimoto's thyroiditis and Melkersson-Rosenthal syndrome. Journal of Medical Microbiology, 59, 137-139.

[77] Sisto, M., Cucci, L., D’Amore, M., Dow, T.C., Mitolo, V. and Lisi, S. (2010) Proposing a relationship between Mycobacterium avium subspecies paratuberculosis infection and Hashimoto's thyroiditis. Scandinavian Journal of Infectious Diseases, 42, 787-790. doi:10.3109/00365541003762306

[78] Cossu, D., Cocco, E., Paccagnini, D., Masala, S., Ahmed, N., et al. (2011) Association of Mycobacterium avium subsp. paratuberculosis with multiple sclerosis in Sardinian patients. PLoS One, 6, e18482. doi:10.1371/journal.pone.0018482

[79] Gazouli, M., Sechi, L., Paccagnini, D., Sotgiu, S., Arru, G., et al. (2008) NRAMP1 polymorphism and viral factors in Sardinian multiple sclerosis patients. Canadian Journal of Neurological Sciences, 35, 491-494.

[80] Tavornpanich, S., Johnson, W. O., Anderson, R.J. and Gardner, I.A. (2008) Herd characteristics and management practices associated with seroprevalence of $\mathrm{Myco}$ bacterium avium subspecies paratuberculosis infection in dairy herds. American Journal of Veterinary Research, 69, 904-911. doi:10.2460/ajvr.69.7.904

[81] http://www.tseandfoodsafety.org/paratuberculosis.html

[82] Click, R.E. and Van Kampen, C.L. (2010) Assessment of Dietzia subsp. C79793-74 for treatment of cattle with evidence of paratuberculosis. Virulence, 1, 145-155. doi:10.4161/viru.1.3.10897

[83] Click, R.E. and Van Kampen, C.L. (2009) Short communication: Progression of Johne's disease curtailed by a 
probiotic. Journal of Dairy Science, 92, 4846-4851. doi:10.3168/jds.2009-2129

[84] Click, R.E. (2011) Successful treatment of asymptomatic or clinically terminal bovine Mycobacterium avium subspecies paratuberculosis infection (Johne's disease) with the bacterium Dietzia used as a probiotic alone or in combination with dexamethasone: Adaption to chronic human diarrheal diseases. Virulence, 2, 131-143.

[85] Kormendy, B. (1994) The effect of vaccination on the prevalence of paratuberculosis in large dairy herds. Veterinary Microbiology, 41, 117-125. doi:10.1016/0378-1135(94)90141-4

[86] van Schaik, G., Kalis, C.H., Benedictus, G., Dijkhuizen, A.A. and Huirne, R.B. (1996) Cost-benefit analysis of vaccination against paratuberculosis in dairy cattle. Veterinary Record, 139, 624-627.

[87] Gwozdz, J.M., Thompson, K.G., Manktelow, B.W., Murray, A. and West, D.M. (2000) Vaccination against paratuberculosis of lambs already infected experimentally with Mycobacterium avium subspecies paratuberculosis. Australian Veterinary Journal, 78, 560-566. doi:10.1111/j.1751-0813.2000.tb11902.x

[88] Mackintosh, C.G., Labes, R.E. and Griffin, J.F. (2005) The effect of Johne's vaccination on tuberculin testing in farmed red deer (Cervus elaphus). New Zealand Veterinary Journal, 53, 216. $\underline{\text { doi: } 10.1080 / 00480169.2005 .36549}$
[89] Sechi, L.A., Mara, L., Cappai, P., Frothingam, R., Ortu, S., Leoni, A., Ahmed, N. and Zanetti, S. (2006) Immunization with DNA vaccines encoding different mycobacterial antigens elicits a Th1 type immune response in lambs and protects against Mycobacterium avium subspecies paratuberculosis infection. Vaccine, 24, 229-235. doi:10.1016/j.vaccine.2005.08.086

[90] Borody, T.J., Bilkey, S., Wettstein, A.R., Leis, S., Pang, G. and Tye, S. (2007) Anti-mycobacterial therapy in Crohn's disease heals mucosa with longitudinal scars. Digestive Diseases Sciences, 39, 438-444. doi:10.1016/j.dld.2007.01.008

[91] Hermon-Taylor, J. (2002) Treatment with drugs active against Mycobacterium avium subspecies paratuberculosis can heal Crohn's disease: More evidence for a neglected public health tragedy. Digestive and Liver Disease, 34, 9-12. doi:10.1016/S1590-8658(02)80052-4

[92] Bull, T.J., Gilbert, S.C., Sridhar, S., Linedale, R., Dierkes, N., Sidi-Boumedine, K. and Hermon-Taylor, J. (2007) A novel multi-antigen virally vectored vaccine against $M y$ cobacterium avium subspecies paratuberculosis. PLoS One, 2, e1229. doi:10.1371/journal.pone.0001229

[93] Tao, B., Pietropaolo, M., Atkinson, M., Schatz, D. and Taylor, D. (2010) Estimating the cost of type 1 diabetes in the US: A propensity score matching method. PLoS One, 5, e11501. doi:10.1371/journal.pone.0011501 